\title{
O predomínio das memórias frente ao romance nas narrativas a respeito da ditadura militar brasileira
}

\author{
The prevalence of the memoir over the novel \\ in narratives about the Brazilian military dictatorship \\ El predominio de las memorias ante la novela \\ en las narrativas respecto a la dictadura militar brasileña
}

Marana Borges ${ }^{*}$

\section{Resumo}

Este artigo analisa o declínio gradual na produção de romances sobre a ditadura militar brasileira (1964-1985) e a ascensão das memórias, gênero a tal ponto difundido que se converteu durante décadas na principal fonte histórica sobre o período, como mostra o historiador Carlos Fico. As memórias são ainda hoje largamente mais publicadas do que os romances. Para explicar o fenômeno, articulam-se argumentos epistemológicos, literários e históricos, lançando mão especialmente de teóricos como Merton, Russell, Avelar e Fico. O livro Viagem à luta armada (1996), de Carlos Eugênio Paz, servirá de estudo de caso. Defende-se a hipótese de que a preponderância das memórias deve-se: a) à noção de privilégio epistemológico envolvendo as pessoas afetadas diretamente pelo regime ditatorial; b) à noção de que a escrita ficcional não seria fidedigna às versões sobre o passado reivindicadas por diferentes segmentos da sociedade. Ambas noções são questionadas neste artigo.

Palavras-chave: ditadura militar brasileira, romance, história, memórias.

\begin{abstract}
This paper explains the gradual decline of novels about the Brazilian military dictatorship (1964-1985) and the rise of the memoir genre, to such an extent that the latter has become the main historical source for decades, according to the historian Carlos Fico. The memoir narratives are hitherto far more published than novels. Justification for this draws on Merton, Russell, Avelar, and Fico to bring together epistemological, literary, and historical arguments. Carlos Eugênio Paz's Viagem à luta armada (1996) is used as a case study. We suggest that the prevalence of the memoir genre is due to: a) the idea of an "epistemological privilege" regarding those people directly affected by the dictatorship; b) the concern that fiction could mislead the versions of the past taken to be true by different groups. This essay challenges both positions.
\end{abstract}

Keywords: Brazilian military dictatorship, novel, history, memoirs.

\begin{abstract}
Resumen
Este artículo indaga sobre el gradual declive de las novelas sobre la dictadura militar brasileña (19641985) y la emergencia del género de las memorias, hasta tal punto de convertirse en la principal fuente histórica durante décadas, según el historiador Carlos Fico. Actualmente, las memorias siguem publicándose más que las novelas. Para explicar este fenómeno, se tendrán en cuenta teóricos como Merton, Russell, Avelar e Fico para sostener argumentos epistemológicos, literarios e históricos. El libro de memorias Viagem à luta armada (1996), de Carlos Eugênio Paz, servirá de estudio de caso. A lo largo de este artículo, se pretende demostrar que el predominio de las memorias se debe: a) a la noción de "privilegio epistemológico" con respecto a quienes sufrieron directamente el régimen; b) al temor de que la ficción no sea fidedigna a la construcción de las versiones sobre el pasado defendidas por distintos sectores de la sociedad. Este artículo cuestiona estas nociones.
\end{abstract}

Palabras-clave: dictadura militar brasileña, novela, historia, memorias.

\footnotetext{
* Doutoranda em Teoria da Literatura na Faculdade de Letras da Universidade de Lisboa, Lisboa, Portugal. (Dorcid.org/ https://orcid.org/0000-0002-8366-2418. E-mail: maranaborges@gmail.com
} 
O gênero das memórias é amplamente apontado como uma das principais marcas das narrativas sobre a última ditadura militar brasileira. Essa presença do memorialismo contrapõe-se a do romance, tanto no número de produções editoriais quanto na sua aceitação. Ao longo deste artigo, tento explicar senão a ausência, ao menos o lugar periférico do romance sobre a ditadura. ${ }^{1}$ Os argumentos propostos mobilizam e articulam fatores epistemológicos, históricos e literários.

A memorialística ganhou especial força no final dos anos 1970, com a Lei da Anistia, o regresso de exilados e, a partir dos anos 1980, com a abertura política e o arrefecimento da censura, transformando-se em um boom editorial que dura até os dias atuais. Carlos Fico (2004, p. 31) considera a memorialística "o primeiro conjunto de versões sobre o período". Mais do que isso, enquanto gênero, o memorialismo pouco a pouco ocupou o lugar do romance, como mostra a crítica literária Walnice Nogueira Galvão:

O memorialismo, literatura típica de velhos, de repente passa a ser feito por jovens que antes dos 30 anos já têm reminiscências terríveis para contar. Embora leve mais de dez anos para aparecer, é consequência direta de 64. A pressão do totalitarismo acuou rapazes e moças no rumo das armas, assassinou-os, seviciou-os, fez deles clandestinos e desenraizados. $\mathrm{O}$ memorialismo resultante, que tem a peculiaridade de ser feito por jovens num gênero típico da velhice, não terminou até hoje (Galvão, 2004).

A passagem do romance às memórias é crucial. Segundo depreende-se do excerto supracitado, a situação excepcional vivida por militantes opositores teria sido de tal ordem que os levou a querer contar as memórias de suas trajetórias pessoais na luta contra o regime, e a fazê-lo pela escrita, em primeira pessoa.

Por que o número de romances que tratam do tema sofreu paulatinamente um declínio? A tomar como pista a citação de Galvão, cabe perguntar se terá sido porque os romancistas não tivessem memórias terríveis para contar. Ou será por que aquilo que se pretendia contar não se acomodava na ficção? Ou, ainda, por não bastar ter reminiscências terríveis para se escrever um romance?

Este artigo ancora-se nas relações entre ficção e memórias. A fim de analisar melhor o problema, tomarei o livro Viagem à luta Armada, de Carlos Eugênio Paz. ${ }^{2}$ A escolha da obra, ainda pouco analisada pela crítica acadêmica, justifica-se pela dificuldade que o texto apresenta especialmente quanto ao gênero. O livro, considerado à partida uma narrativa memorialista, evidencia um hibridismo ao confluir elementos próprios da ficção. Além disso, a obra, tendo sido escrita por um autor de grande liderança na época em que os fatos retratados teriam ocorrido, expõe de modo contundente o que chamarei de privilégio epistemológico, uma das razões que explica a hipertrofia do memorialismo sobre a ditadura.

A crítica que analisa a ficção sobre a ditadura brasileira dedica-se, com frequência e sobretudo, àquela produzida durante o Estado de exceção, relacionada especialmente ao período de maior repressão militar, no final dos anos 1960 e nos anos 1970 (Franco, 1998a, 1998b, 2015; Pellegrini, 1987; Dalcastagnè, 1996). Em comum, tais trabalhos enfatizam as renovações da linguagem observadas em parte das obras - desde o descentramento do foco narrativo ao recurso da montagem e fragmentação - como uma resposta às novas condições de produção impostas pelo regime. Destacam-se Quarup (1967) e Reflexos do Baile (1976), de Antônio Callado, Zero (1974), de Ignácio de Loyola Brandão, e A Festa (1976), de Ivan Ângelo, entre outros.

Em todo caso, o foco deste artigo não é a produção literária dos anos 1970, mas o declínio, após os anos 1970 até os dias atuais, da ficção a respeito da ditadura. Como hipótese a ser testada, sugiro que a preferência pelas memórias e não pela escrita romanesca, explicitamente ficcional, deve-se principalmente à articulação de dois fatores: i) à ideia de que certas experiências autorizam seus atores a descrevê-las; e ii) à noção de que a escrita ficcional pode

\footnotetext{
${ }^{1}$ Com isso me refiro às narrativas ficcionais longas nas quais a referência à ditadura militar brasileira exerce um papel de destaque no enredo.

${ }^{2}$ Nenhum dos escassos estudos acadêmicos sobre a obra de Paz propõe-se articular uma análise do embate entre os gêneros romanesco e memorialístico no contexto do declínio da produção ficcional sobre a ditadura brasileira. Entre os estudos sobre o livro já realizados, destacam-se o de Maria Cláudia Badan Ribeiro (2005) e o de Marina Silva Ruivo (2005).
} 
ser lesiva à construção das versões sobre o passado defendidas como historicamente "verdadeiras" por diferentes segmentos da sociedade.

As seções a seguir tratarão de cada um desses fatores e, na sequência, será analisado como a proximidade histórica em relação aos eventos traumáticos da ditadura militar e aos seus efeitos nas vidas individuais e familiares contribuiu para o predomínio das memórias. Finalmente, a última seção, além de encadear os argumentos anteriormente expostos, aponta para a existência de uma tímida, mas não menos importante, retomada do romance.

\section{A epistemologia do insider}

Para ajudar a refletir sobre este tópico, relato uma situação pessoal ocorrida em 2015, quando travei contato com diversos interlocutores que haviam vivido durante a ditadura militar, com vistas a preparar um romance sobre o período. Durante as conversas, várias pessoas me perguntavam: "Como você pode escrever sobre isso se não passou pela ditadura?"

Essa pergunta, endereçada de modo informal, mas em tom reprovador, revela algumas ideias importantes que explicam, em parte, a reduzida produção romanesca. Elas estão disseminadas nos discursos sobre a ditadura brasileira - é o que ocorre, como veremos, em Viagem à luta Armada, de Carlos Eugênio Paz. Tais premissas não constituem uma prática institucionalizada ou sobre cujos motivos se presta a atenção devida. Ao contrário, são reproduzidas e aceitas geralmente de modo tácito e, por isso, tendem a suscitar pouca crítica.

Em jogo está a ideia de medir a fiabilidade de um discurso pelas credenciais de seu autor. Nesse caso, tais credenciais têm a ver com a presença, na biografia do autor, de uma experiência pessoal e direta com a ditadura - preferencialmente traumática, como veremos -que ao mesmo tempo informe e justifique a escrita.

A defesa de que o autor deva necessariamente passar pelo que ele pretende narrar habilita apenas uma classe de pessoas como sendo apta para a escrita romanesca. Surge um problema epistemológico: a primazia de certas pessoas no acesso a um tipo de conhecimento que, mais tarde, justificará uma prática literária.

A essa primazia chamarei privilégio epistemológico, como refere Merton (1972). Não se trata de um fenômeno exclusivo da produção literária sobre a ditadura. É comum ouvir exemplos do gênero: "Só quem tem um filho sabe o que é tê-lo (ou perdê-lo)", "Só quem já sofreu racismo sabe o que é isso" etc. Tais enunciados sugerem a seguinte relação de causalidade: primeiro, vivemos algo de significativo a que denominamos, de modo vago, uma "vivência"; ao fazê-lo, conhecemos e aprendemos do que se trata essa vivência; e, finalmente, podemos falar e descrevê-la. Não somente podemos como, se o fizermos, teremos a garantia de que o relato será correto e fiável.

Os problemas dessa posição são muitos. O fato de algumas vivências nos mudarem ou nos ensinarem é algo imensurável, imprevisto e irreplicável. Mesmo ao assumir que experiências podem (embora não necessariamente) ser pedagógicas, como o fato de conhecê-las assegura que serão descritas corretamente? Afinal, o que é uma descrição correta? A relação causal direta entre relato e experiência leva a que o único método para verificar a correção do relato seja contrapondo-o às suas causas, isto é, à vivência, sempre privada e idiossincrática. O autor da descrição seria também seu próprio juiz, o que comprometeria a arbitragem sobre a correção universal do relato.

As escritas autobiográfica e memorialística ${ }^{3}$ apelam mais facilmente a essa posição; é recorrente pensar que aquilo de que me lembro a respeito de mim mesmo, bem como aquilo que digo que me lembro é, a priori, mais confiável. Contudo, da minha vida, sou a um só tempo o protagonista e uma testemunha interessada. Esse aspecto não pode ser menosprezado, sobretudo quando a escrita das memórias reivindica um cunho historiográfico.

\footnotetext{
${ }^{3} \mathrm{O}$ memorialismo inclui memórias, autobiografias, diários e correspondências nas quais a memória representa o elemento principal. A amplitude do conceito, contudo, é muitas vezes problemática para o pesquisador, daí a importância de algumas distinções. A mais aceita enfatiza nas memórias as referências extrínsecas e factuais do autor (sua profissão, o contexto político, social, econômico e histórico que descreve etc.); já no texto autobiográfico predomina o teor mais reflexivo, pessoal e intimista, conforme descreve Mathias (2001). Em ambos, há uma coincidência entre as figuras de autor, narrador e protagonista, como Lejeune (1989) famosamente mostrou.
} 
Para melhor analisar o privilégio epistemológico no contexto da ditadura militar brasileira, tomo o já mencionado livro Viagem à luta armada. O autor foi o último comandante da Ação Libertadora Nacional (ALN), a maior organização de esquerda engajada na luta armada, e o único a não ser preso nem assassinado. Ao longo do relato, publicado em 1996, intercalam-se memórias do exílio na França com a narração da atuação política no Brasil. Como se vê ao longo do texto, a experiência radical na guerrilha urbana lhe teria dado autoridade e acesso a um conhecimento privilegiado para falar sobre o passado: compreendê-lo é para poucos; escrever sobre a memória coletiva é tarefa ainda mais seleta.

Companheiro, ternura... ternura, companheira... Direi essas palavras quantas vezes for preciso, ainda que rompa os estilos, que fira a sensibilidade dos literatos e dos que não viverame não podem compreender. Era uma época de excessos, exceções existiram, mas demos a vida por ternura e companheirismo (Paz, 2009, p. 162, grifo nosso).

Um ponto importante para entender a posição do autor, que em geral coloca-se como alguém em posição privilegiada e visionária em relação aos fatos narrados, ${ }^{4}$ é elucidado por Merton, quando analisa o papel de insiders e outsiders na sociologia do conhecimento. Segundo ele, quanto mais polarizada a sociedade, mais os grupos em conflito disputam a prerrogativa de acesso à verdade. A doutrina do insider postula o monopólio ou o privilégio no acesso a certo tipo de conhecimento àqueles que tiveram certas experiências. $\mathrm{O}$ insider, membro de um determinado grupo social ou detentor de um determinado estatuto social, seria "alguém dotado de uma compreensão especial sobre questões necessariamente obscuras para os outros" (Merton, 1972, p. 11, tradução nossa). Os demais, os outsiders, somente conseguiriam adquirir o referido conhecimento a um custo muito grande e, não raras vezes, inalcançável.

No limite, tal doutrina culmina no solipsismo metodológico: a ideia de que tudo quanto uma pessoa realmente conhece advém de sua experiência subjetiva e direta. Os problemas agravamse ao se considerar as credenciais do enunciador como inatas, e não adquiridas. Assim, um negro ou uma mulher conheceriam necessariamente melhor a situação dos grupos aos quais pertencem do que um branco ou um homem, respectivamente.

Nas antípodas dessa doutrina, outra abordagem confere aos outsiders o privilégio do conhecimento. Pelo fato de se situarem fora do grupo sobre o qual falam, teriam uma perspectiva mais independente e, portanto, mais crítica e melhor.

Um dos erros de ambos os princípios é pressupor que pertencemos apenas a um grupo e, portanto, somos full insiders/outsiders. Ao contrário, Merton mostra que as identidades sociais são dinâmicas e é o contexto onde as pessoas se encontram que definirá se elas serão insiders ou outsiders: "Situações diferentes mobilizam posições distintas, as quais logo passam a dominar as reivindicações contrárias de outras posições" (Merton, 1972, p. 25, tradução nossa). O principal argumento de Merton é o de que o conhecimento usufrui de alguma autonomia, isto é, não pode ser totalmente determinado apenas pelo nosso lugar social.

É preciso pontuar que Merton, como sociólogo, preocupa-se com as chamadas minorias que emergem nos Estados Unidos nos anos 1960. Unificar sob o mesmo grupo social toda a esquerda brasileira seria, contudo, arriscado. Mesmo se as categorias de insider/outsider não possam ser prontamente transferidas ao contexto da ditadura militar brasileira, penso ser produtivo questionar, a partir dessas categorias, o lugar e os interesses daqueles que desconfiam da escrita romanesca, realizada por outsiders, sobre o regime ditatorial.

Em Viagem à luta armada há acontecimentos pelos quais tão poucas pessoas passaram a ponto de tornar o relato sobre eles algo exclusivo de certos atores. Essa posição de poder é ocupada pelo narrador, mas também partilhada com alguns de seus pares. É o que acontece quando o tema é a tortura. O narrador, que nunca foi torturado, conversa com Carlos Marighela, líder comunista da ALN que sofrera nas celas ainda durante a ditadura de Getúlio Vargas. O narrador, referindo-se à própria irmã, que acabava de ser presa e torturada, diz a Marighela:

\footnotetext{
4 A posição, contudo, oscila, pois em situações muito específicas (como no caso de execuções de militantes) o narrador responsabiliza retrospectivamente seu erro pela excepcionalidade da experiência e pelas limitações próprias de sua geração.
} 
"Você sabe como é, já passou por isso". E Marighela lhe responde: "- É o momento em que estamos mais terrivelmente sós, quem não viveu não pode entender" (Paz, 2009, p. 116).

Ao avalizar a opinião de Marighela, o narrador assume o papel de um outsider convertido: aquele que se torna "ainda mais zeloso que os insiders ao aderir à doutrina do grupo com o qual ele quer se identificar, ainda que simbolicamente" (Merton, 1972, p. 20, tradução nossa). Em todo caso, é curioso notar que, no livro, o privilégio no acesso ao conhecimento é sistematicamente dado ao insider, e não ao outsider. Nesse exemplo específico, o personagem beneficia-se de ambos os estatutos (afinal, é enquanto um militante/insider famoso que conversa com Marighela), daí sua superioridade.

A guerrilha urbana é descrita como uma situação excepcional, dinâmica, carregada de adrenalina. É nessa situação de ruptura com a normalidade que se insere o protagonista. Ela lhe oferece aprendizagens importantes, as quais nem todos serão capazes de conseguir:

Aprendemos, com o decorrer dos anos e das fugas, a acordar com os ruídos suspeitos, tipo quatro portas de um carro batendo ao mesmo tempo, sinal de tira [polícia] e de tiros, que podem nos salvar ou nos matar. Perdemos os gestos e o cotidiano banais, a possibilidade de tédio (Paz, 2009, p. 66).

Não se sabe ao certo de onde vêm certas coisas, mas de uma forma ou de outra, aprendi a arte da fuga e ganhei de brinde a sobrevivência. A luta armada nem tinha começado e eu já dominava o escape (Paz, 2009, p. 108).

O autor-narrador, como é comum na escrita autobiográfica sobre o período, é sempre alguém acima dos fatos. Um visionário. Sabe mais que os outros. Mas não se deve esquecer que Paz conta sua vida depois da ditadura, em retrospectiva, fazendo um balanço e uma autocrítica que dificilmente seria possível durante o auge da luta armada. ${ }^{5}$

O momento em que o protagonista - ao mesmo tempo uma testemunha ocular - mais usufrui da autoridade sobre a realidade relatada é, sem dúvida, em relação à traição cometida por Cabo Anselmo (no livro, Silvério), hoje visto como o principal infiltrado na esquerda armada. O narrador diz ter sabido, desde o primeiro momento, que Silvério era um traidor. Ninguém concordou, qualificando-o de paranoico.

Se bastasse passar por certas experiências para conhecê-las, então o protagonista jamais saberia que Silvério era um traidor, uma vez que o próprio protagonista nunca havia sido traído. Portanto, no livro também estão em jogo tipos de conhecimentos que não resultam das experiências diretas, como é o caso da intuição. Seja em um caso ou no outro, o privilégio epistemológico segue presente: no primeiro, ele é conferido àqueles que viveram diretamente os percalços da ditadura; no segundo, ele é ainda mais elitista, pois dispensa e se sobrepõe à experiência direta até então tão prezada, tornando-se excepcional e inacessível.

Mas o protagonista também se engana. Seus erros, contudo, justificam-se à luz da excepcionalidade das experiências vividas. É o caso da execução de um membro da ALN, por suspeita de traição - suspeita nunca confirmada.

Foi terrível... hoje não me interessa se tínhamos ou não razão, quero falar, contar... ajudar a que nunca mais um agrupamento de seres humanos tenha direito a tal escolha... já posso me encarar, não importa que outros não assumam [a responsabilidade] comigo, prometi a Felipe prestar contas à História... Mário não pode passar por traidor, e os companheiros que tomaram a decisão e executaram a sentença não podem ser conhecidos como gritos e assassinos políticos que matavam para tomar o poder na Organização (Paz, 2009, p. 187).

Ao introduzir seus enganos e erros, a figura do narrador torna-se mais complexa e ambígua, oscilando entre duas posições maiores. De um lado, a posição de "prestação de contas": o narrador quer justificar suas ações individuais com base nos limites e imperfeições do contexto social da época, sem deixar de reivindicar uma versão (a sua) da história, para a qual busca a

\footnotetext{
${ }^{5}$ A dificuldade de formulação, circulação e/ou aceitação de críticas feitas pelos próprios membros às organizações políticas clandestinas durante o período de luta armada é mencionada em diversas obras além da de Paz, como no romance Em câmera lenta, de Renato Tapajós (1977), em O que é isso, companheiro?, de Fernando Gabeira (1979), e nas memórias Náufrago da utopia, de Celso Lungaretti (2005), entre outras.
} 
adesão do leitor. De outro lado, diz pretender apenas fazer um registro autobiográfico, pessoal, intimista e, portanto, parcial, sem qualquer teor ou implicação coletiva nem historiográfica.

A segunda tendência parece surgir como uma espécie de indulto pelos momentos nos quais o discurso assertivo do autor sobre a realidade geral não dá conta de explicá-la. $\mathrm{Na}$ impossibilidade de uma descrição totalizante e definitiva do passado, o narrador salvaguardase na narração intimista, lugar não sujeito às qualificações de correto ou falso.

Quer se trate de uma versão que se reivindica coletiva ou que pretende ser individual, o autor-narrador aventa a posse privilegiada do conhecimento, sem nunca colocar em causa o tipo de conhecimento em si. A existência de variadas formas de conhecimento é de fulcral importância para questionar tal privilégio.

Algumas distinções feitas por Bertrand Russell são de especial importância. O filósofo estabelece uma diferença entre o que chama de conhecimento direto ou por contato (knowledge by acquaintance) e conhecimento por descrição (knowledge by description). Sobre o primeiro, o filósofo diz: "Digo que conheço diretamente [I am acquainted with] um objeto quando tenho uma relação cognitiva direta com esse objeto, ou seja, quando estou diretamente consciente do objeto em si" (Russell, 1918, p. 209, tradução nossa).

Em contrapartida, o knowledge by description é obtido pelo intermédio de inferências. É ele que nos permite conhecer, por exemplo, Júlio César. "É óbvio que Júlio César não está, ele próprio, na nossa mente", mas certas descrições sobre ele: "'o homem que foi assassinado nos idos de março', 'o fundador do Império Romano'" (Russell, 1912/2001, p. 32, tradução nossa). Conhecer Júlio César, nesse caso, não é conhecê-lo diretamente, mas, sim, conhecer uma descrição sobre ele.

A relevância da "descrição" reside em ampliar nossas formas de conhecimento, e dela inevitavelmente (e felizmente) lançamos mão:

A principal importância do conhecimento pela descrição é que ele nos permite ultrapassar os limites da nossa experiência particular. [...] Por meio da descrição, podemos ter conhecimento de coisas que nunca experimentamos. Diante do alcance limitado de nossa experiência imediata, este resultado é essencial (Russell, 1912/2001, p. 32, tradução nossa).

No que se refere ao tema deste artigo, as definições de Russell são relevantes. Somos necessariamente dependentes de descrições. Se somente houver autorização para falar depois de se passar por uma experiência em primeira mão, então o único relato possível será a autobiografia em stricto sensu. Mais do que isso, o conhecimento da história acabaria no momento em que morressem as pessoas que viveram (e, portanto, seriam autorizadas a falar) certos eventos.

A percepção de um campo reservado para certas pessoas é uma das razões para o predomínio das memórias sobre os romances. Também explica, a meu ver, por que as memórias constituíram o primeiro corpus dos historiadores a respeito da ditadura militar (Fico, 2004). Considerou-se, no início, que elas reproduziam os fatos tais e como ocorreram no passado e, portanto, mereciam atenção privilegiada. Não poucas vezes, como mostrou Fico, foram vistas como facilitadoras do acesso à verdade, e não encaradas primordialmente como objetos de estudo.

\section{Os "prejuízos" da ficção}

No contexto da ditadura militar, a primazia das memórias diante do romance parece resultar - para além do privilégio epistemológico conferido ao insider que se viu no tópico anterior também do temor à imaginação: o romance, por excelência vincado na imaginação, poderia deturpar o passado. ${ }^{6}$ Trata-se de uma atitude de encarar o passado como um acervo de fatos indiscutíveis, acessíveis a certos narradores e somente representáveis corretamente em determinadas narrativas, supostamente mais objetivas.

\footnotetext{
${ }^{6}$ Isso explica igualmente por que o discurso histórico e o jornalístico não são desvalorizados a priori enquanto gêneros suspeitos ou infiéis no que se refere à narração sobre a ditadura brasileira. Pensa-se que eles, por estarem supostamente a salvo da imaginação, poderiam potencialmente representar de modo fidedigno o "real". Esquece-se, porém, do caráter subjetivo da linguagem.
} 
Ainda de acordo com essa posição, a ficção é por vezes vista como uma espécie de caricatura perante certos traumas, como aqueles relacionados à ditadura. Isto é, a ficção, por sua infidedignidade, não estaria à altura da relevância, da excepcionalidade e da carga emocional de sofrimento do trauma para poder narrá-lo de modo adequado.

Cabe aqui analisar em mais pormenor a questão do trauma para saber se ela esclarece o lugar periférico do romance. O conceito de trauma, originário da psicanálise, descreve um conteúdo psíquico intolerável do qual o sujeito evita aproximar-se, dado estar associado a um acontecimento doloroso insuperável. Ele é, em outras palavras, "a memória de um passado que não passa" (Seligmann-Silva, 2008, p. 69).

Originariamente, o trauma diz respeito à psique de um indivíduo. O genocídio dos judeus na Segunda Guerra Mundial constituiu-se por excelência na noção de trauma coletivo. Com ela, uma extensa produção teórica veio apontar a dificuldade de elaboração verbal do trauma. Alguns críticos, como Dori Laub (1995), sinalizaram a impossibilidade de narração após o Holocausto. O trauma seria, em última instância, irrepresentável e inenarrável. Ter-se-ia estabelecido, como também aponta o historiador Alexandre de Sá Avelar, a "fenda entre o evento e a linguagem, entre o dado inimaginável da experiência e o maquinário linguístico disponível para representá-la" (Avelar, 2012, p. 37). ${ }^{7}$

Articular verbal e racionalmente uma experiência em si irrepresentável correria o risco de "reduzir seu impacto", conforme constata (embora não defenda) Jaime Ginzburg (2001, p. 132). Ao fazê-lo, a consequência seria uma generalização da experiência, anulando a própria natureza de estranheza da qual o trauma depende. Isso toca de modo particular o problema deste artigo. Parece ser esse risco que se teme em relação ao papel que a ficção poderia desempenhar como narrativa da ditadura brasileira: o de atrofiar a magnitude de um trauma coletivo advindo de uma catástrofe histórica.

Muito do pensamento desenvolvido na esteira do Holocausto foi apropriado para se pensar as narrativas produzidas pelos sobreviventes das ditaduras latinoamericanas dos anos $1960 \mathrm{e}$ 1970. Segundo essa linha de análise, os discursos da tortura também lidariam com a categoria do trauma e, portanto, se deparariam com o paradoxo do irrepresentável.

Notemos, contudo, uma situação contraditória: ao mesmo tempo que se enfatiza a desconfiança em relação à linguagem para narrar o traumático ocorrido nos "porões do regime", dois tipos de texto historicamente ocuparam um espaço privilegiado na produção literária e amplamente aceito pelo mercado editorial: as memórias e o testemunho - também eles representações:

A proliferação de narrativas memorialísticas tornou-se comum em sociedades que passaram por experiências traumáticas como guerras, "terrorismo", revoluções, ditaduras, tiranias e totalitarismos, evidenciando o intenso laço entre os testemunhos e a política (Cardoso, 2012, p. 31).

A profusão do memorialismo vem provar que a condição do trauma enquanto conteúdo inenarrável não é suficiente para explicar a ausência do romance como narrativa principal sobre a ditadura brasileira. Não se evitam todas as formas literárias, mas algumas. Parece que o temor de atrofiar ou falsear a magnitude da experiência vivida - temor este típico de toda tentativa de representar o trauma, como foi dito - é particularmente sensível (e por vezes reticente) à aceitação do romance enquanto uma forma possível de veicular a realidade que se quer lembrar e transmitir.

Específico ao romance é a percepção generalizada, mas incorreta, de qualificá-lo como discurso da imaginação, distante da "realidade". Incorreta porque categorias como "real" e "realidade" são sempre construções da linguagem e, como tais, essas construções estão permeadas pela imaginação. É o fato mesmo de a linguagem ser inexoravelmente permeável à imaginação que impede a tentativa de excluir a imaginação de um texto, seja na escrita memorialística ou romanesca.

\footnotetext{
${ }^{7}$ Avelar, contudo, critica a "insuficiência teórica dessa impossibilidade", seja pela falta de testemunhas plenas (as que morreram nos campos de concentração), seja pelo suposto interdito da linguagem.
} 
Os próprios testemunhos de sobreviventes de catástrofes históricas, por vezes encarados como mais aptos a descrever objetivamente o passado, são permeáveis à imaginação. Como mostram Avelar (2012) e Seligmann-Silva (2008), ela vem sempre cobrir as carências diante das dificuldades afetivas e linguísticas de falar sobre o trauma e construir o testemunho. Este é sempre figurativo (Tozzi, 2012), inclusive quando apresenta um estilo linguístico mais próximo ao científico.

A ideia de que o testemunho oferece uma representação histórica privilegiada e direta do passado deve ser posta em questão. Avelar (2013, p. 30) nota como “esse retorno do 'eu' sob a forma testemunhal tem sido largamente usado como critério de legitimação dos discursos sobre o passado", o que, penso, aplica-se no caso das narrativas sobre a ditadura brasileira.

Isso não significa eliminar a existência de gêneros, nem fazer equivaler testemunho e romance ou testemunho e história ou mesmo romance e história, mas perceber o hibridismo de algumas narrativas e a presença da imaginação como elemento inerente à própria linguagem.

O grau e a intenção com que se faz uso da imaginação e como ela é interpretada pelo leitor pode diferir conforme o gênero. $O$ tipo de pacto estabelecido entre autor e leitor separa a escrita de memórias da escrita explicitamente ficcional. Em relação à primeira, há um compromisso do narrador em contar aquilo que viu, ouviu, viveu - e uma confiança por parte do leitor de que ele assim o fará. Daí que a figura da testemunha ocular da história, ao mesmo tempo protagonista da narrativa, seja um recurso importante da memorialística.

Confia-se em primeiro lugar na capacidade cognitiva de um outro, na sua capacidade pura e simples de presenciar, com olho, ouvido (olfato, tato e paladar) e cérebro bem conformados. O campo da confiança, aliás, amplia-se. Se a testemunha pretende enunciar a verdade, se está comprometida moralmente, também o interlocutor há de receber com confiança as palavras (Kolleritz, 2004, p. 74).

Não se pode deixar de considerar que, na maioria das vezes, as testemunhas oculares são, no que se refere à ditadura militar, ao mesmo tempo vítimas. No caso de uma situação-limite como um regime de exceção, não é difícil supor o possível ressentimento presente em suas narrativas. Menosprezar esses fatos dificulta a interpretação crítica das memórias.

Em Viagem à luta armada, a figura da testemunha ocular é basilar. No prefácio, Franklin Martins dá autoridade e anuência ao relato precisamente porque, como parte de segmento estrito de leitores (os "insiders"), ele teria passado por vivências semelhantes:

Viagem à luta armada é um bom livro. Talvez seja mesmo um excelente livro. Não falo como crítico literário, que não sou, mas como alguém que viajou as mesmas viagens dessas páginas e nelas se reconheceu e com elas se emocionou e se indignou e se torturou e se abateu e se reconstruiu (Paz, 2009, p. 8).

Como fica explícito, não está em causa um reconhecimento do ponto de vista estritamente literário: Martins, enquanto um sobrevivente, quer ver seu próprio passado representado no passado de outro.

Mas é justamente a questão literária e textual do livro que interessa analisar. A obra coloca desafios adicionais à interpretação, pois traz elementos de vários gêneros. Tal qual a autobiografia, possui uma dimensão de justificativa de ações do autor-narrador. Tal qual as memórias, que "tendem à redescoberta ou confirmação do que somos na dimensão íntima de um tempo nosso que morrerá conosco" (Mathias, 2001, p. 164), o texto fala da autodescoberta de Eugênio Paz.

Ainda mais interessante, a obra utiliza diversos recursos comuns à narrativa ficcional: a ficcionalização dos nomes dos personagens; a variedade temporal; um enredo carregado de peripécias; a narração construída de forma a obter uma oscilação constante entre tensão e distensão. O leitor tem a sensação de ler um romance (ou uma novela, dada a curta extensão do texto; para todos os efeitos, a distinção aqui é irrevelante), ao mesmo tempo que sabe, porque assim foi avisado desde o subtítulo ("memórias da guerrilha"), que está a ler o relato de eventos que ocorreram. Se isso é assim, por que razão se ficcionalizam os nomes? Carlos Marighela vira Fabiano; cabo Anselmo, Silvério; Clemente, o codinome do narrador-autor, torna-se Clamart.

Meu argumento é o de que a coexistência de elementos ficcionais dentro de uma narrativa de testemunho e memorialista, como é o caso de Viagem à luta armada, não é gratuita nem se presta 
apenas a tornar a leitura mais entretida, como poderia parecer à primeira vista. Tampouco a ficcionalização dos nomes visa preservar as identidades reais dos personagens. Qualquer leitor bem informado sobre o período reconheceria boa parte dos personagens citados.

Os elementos romanescos servem para o texto se beneficiar de um duplo estatuto: por um lado, mantém-se uma particularidade que se crê restrita ao romance, isto é, o descompromisso com o referente; por outro, ao não se instituir como romance, mas memórias, o texto garante a almejada veracidade dos fatos relatados. A ocorrência de recursos ficcionais e um estilo literário próprio do romance desculpa o texto e seu autor por possíveis "desvios" dos fatos; concomitantemente, reivindica-se o grau de verdade histórica por meio da categorização do livro ("memórias") e de querer fazê-lo coincidir com a biografia de Paz.

Dito de outra forma, as memórias, porque supostamente não ficcionais e, portanto, não imaginadas, avalizariam a fidelidade à realidade. Ao apostar também em elementos ficcionais, ficaria assim assegurada a absolvição do autor por qualquer equívoco face à realidade, o qual seria justificado à luz da ficção. Em todo caso, o livro sempre se reafirmaria enquanto uma descrição fiel do passado.

É no ato de o autor cortejar a linguagem do romance enquanto tenta ser "objetivo" que algo interessante acontece, talvez imprevisto pelo Paz: acaba por chamar a atenção para a composição inalienável, no interior do gênero das memórias, do figurativo e da imaginação. O temor da imaginação perde sua força, e daí o livro encerrar em sua própria forma, simultaneamente, uma desconfiança e um elogio ao gênero romanesco.

\section{O distanciamento histórico}

Segundo o historiador Carlos Fico, é inevitável a saturação do gênero do testemunho, à medida que a sociedade se afasta dos eventos do passado recente relatados e inclusive com o gradual falecimento das testemunhas oculares: "velhos mitos e estereótipos estão sendo superados, graças tanto à pesquisa histórica factual de perfil profissional quanto ao [...] desprendimento político que o 'distanciamento histórico' possibilita" (Fico, 2004, p. 30). ${ }^{8}$

Com isso não pretendo defender uma relação direta entre a falta de distanciamento histórico e a baixa produção romanesca: não se escreveram romances porque não havia distanciamento histórico. Muitos romances foram escritos no auge da ditadura, como já foi citado aqui. Contudo, parece que a proximidade afetiva com os fatos privilegiou aos poucos os testemunhos e as memórias pelas razões já aqui explicadas. Foram gêneros tão em voga a ponto de se chegar a uma saturação.

Tomemos com atenção o conceito de distanciamento histórico. Grosso modo, ele é entendido como uma passagem do tempo suficiente o bastante para permitir o estudo do passado remoto com maior objetividade e desprendimento afetivo. Tal definição, contudo, é enganosa. Phillips (2003) critica o modo naturalizado de se encarar o distanciamento histórico enquanto algo objetivo e uma consequência inevitável do passar do tempo. Ao contrário, ele sublinha o caráter de construção dessa distância, inerente a toda relação que estabelecemos com o passado, e que vai desde a proximidade mais imediata (immediacy) até o desapego (detachment).

O distanciamento não pode ser auferido linearmente, nem somente com base na cronologia dos anos que passaram. É um processo que implica, em sua construção, uma série de fatores e tensões de ordem ideológica, afetiva, cognitiva e formal da linguagem. Depende, por exemplo, daquilo que uma sociedade julga possível, em um determinado momento, de ser explicado ou entendido.

Uma reportagem de 2011 a respeito do recente boom editorial sobre a ditadura brasileira sinaliza um gradual distanciamento afetivo: "'Há uma valorização da memória da ditadura agora.

\footnotetext{
${ }^{8}$ É preciso matizar o esgotamento dos testemunhos. A maior parte das memórias difundidas abrange alguns segmentos específicos das vítimas diretas da ditadura, em especial aquelas de esquerda e engajadas na luta armada. Para que outros segmentos produzam testemunhos, seriam necessárias condições históricas favoráveis. Isso porque o testemunho não depende somente da vontade ou capacidade individuais em narrar experiências, mas "também está ancorada nas condições sociais que o tornam comunicável, condições que evoluem com o tempo e variam conforme o lugar” (Catela, 2006, p. 13).
} 
De 1985 a 1995, vivemos um momento ainda muito próximo dos fatos; as pessoas estavam machucadas e não queriam falar', comenta Maria Luiza Tucci Carneiro" (Rodrigues, 2011).

Não se sabe se as mencionadas pessoas machucadas seriam autores ou leitores ou ambos. Em todo caso, Tucci Carneiro afirma que, até muito recentemente, o sofrimento das pessoas cujas vidas pessoais foram afetadas pela ditadura coibiu a produção de narrativas.

O que procurei mostrar é que houve, sim, uma larga produção, mas centrada em certos tipos de discurso. Mesmo que durante a ditadura militar tenha havido a publicação de romances sobre o período, o fato de esse gênero ceder espaço às memórias escritas, sobretudo, por ex-militantes de esquerda, parece sugerir a existência gradual, que ainda se estende aos dias atuais, de uma espécie de reivindicação do lugar de fala àqueles para quem o passado ainda não passou.

Para os que estão vivos e têm a biografia marcada por eventos traumáticos, a ditadura não pertence a um passado remoto, daí por vezes alguma preocupação e a insegurança em relação às formas de narrá-lo e preservá-lo contra versões conflitantes de determinados setores da sociedade. Entre essas versões, estariam também as da ficção. Escrever romances quando as pessoas envolvidas na ditadura ainda estão vivas parece suscitar o temor de elaborar interpretações do passado opostas às defendidas pelas vítimas, causando mesmo uma espécie de lesão à memória de pessoas que já teriam sofrido bastante.

A proximidade histórica da sociedade em relação ao regime de exceção no Brasil, se ajudou a constranger a produção romanesca, especialmente de autores sem biografias ligadas à ditadura militar, de algum modo também conformou a escrita historiográfica, cujas fontes até recentemente se apoiaram excessivamente na narrativa memorialista testemunhal.

$\mathrm{Na}$ última década a pesquisa histórica tem gradualmente se voltado a outras fontes e documentos. Essa "nova fase da produção histórica sobre o período" (Fico, 2004, p. 30) é levada a cabo por jovens pesquisadores que não tiveram a experiência, em primeira mão, da luta ou apoio à ditadura. Pode-se supor que, ao libertar-se do monopólio do testemunho como única fonte documental e ao desvincular a biografia imediata do historiador de seu objeto de pesquisa (ampliando, assim, o grupo de atores dedicados à investigação sobre a ditadura militar), houve uma dinamização do estudo do passado e uma maior variedade das áreas de enfoque.

\section{A retomada do romance?}

Em dada altura da história recente do Brasil, deixa-se de escrever romances para escrever memórias: o romance parecia não dar conta nem ser o gênero apropriado para uma escrita que era ao mesmo tempo uma militância política, uma denúncia e um ajuste de contas com a história. O romance, que parecia comprometido demais com a imaginação, acabou em grande medida suplantado pela memorialística.

Ao encadear os diferentes elementos que ainda concorrem para a baixa produção de romances, dei prioridade e articulei argumentos de enfoque social, epistemológico, histórico e literário. Também busquei mostrar a necessidade de se repensar o lugar subalterno da imaginação, uma vez que ela é inerente ao próprio constructo da linguagem.

Apesar de ter me servido da constatação pessoal de censuras informais ao romance e à figura de romancistas que ocupam condição de outsiders, não é o interdito informal à fala que explica o declínio do gênero romanesco e a ascensão da memorialística. Tal interdito é apenas o resultado, e não a causa, dos diferentes fatores elencados ao longo deste artigo.

A escrita ficcional acabou relegada, entre outros fatores, ao ser vista como um desvio e uma lesão à construção da memória coletiva e das versões sobre o passado defendidas como historicamente verdadeiras por diferentes segmentos da sociedade que buscavam adesão. É claro que essa passagem, de forma paulatina, mas consistente, não foi uma conspiração ou agenda programática dos atores envolvidos.

Estaríamos atualmente diante da mesma situação? Creio que não. Paralelamente à maior diversificação das fontes da pesquisa histórica, gostaria de chamar a atenção para dois aspectos. 
O primeiro é o aumento da produção editorial sobre a ditadura nos últimos anos; o segundo é uma incipiente valorização do gênero do romance para tratar o assunto.

Editoras de pequeno, médio e grande porte têm apostado de modo crescente e consistente em livros sobre a ditadura (Rodrigues, 2011). Alguns fatos mostram um sinal de mudanças nas condições históricas que podem permitir quer um maior interesse do público quer um alargamento de perspectivas sobre a ditadura militar: a criação da Comissão da Verdade em 2010; a disponibilização progressiva ao escrutínio público de documentos outrora secretos; e, com algum apelo comercial, efemérides como os cinquenta anos do golpe militar.

Embora a grande parte da produção editorial sobre o tema ainda seja de não ficção, há uma tímida, porém não indiferente, mudança na produção em prosa sobre a ditadura militar, a qual passa a incluir cada vez mais o romance. ${ }^{9}$ Muitas dessas obras ainda são escritas por pessoas que viveram (e sofreram) durante o regime, mas que finalmente se dispõem a falar. O caso de Bernardo Kucinski é o mais emblemático. Isso explica porque, não raro, tais romances fazem cruzar a ficção e a história "factual" de forma mais explícita. Nessas narrativas predomina o tom confessional, o que pode sugerir ainda a implicação pessoal e autobiográfica dos autores nos eventos relatados.

Mais do que um aumento do número de publicações de romances, difícil de ser quantificado, ${ }^{10}$ importa salientar o grande destaque que esse tipo de gênero têm obtido junto ao público. O escritor Godofredo de Oliveira Neto publicou em 2011 a obra Amores exilados, uma versão modificada de um romance publicado em 1997, Pedaço de santo. Em entrevista ao Estado de S. Paulo, ele se diz surpreso ao notar que seu livro obteve muito maior receptividade agora do que há 15 anos, quando o publicou pela primeira vez (Neto, 2011).

Não é descabido supor que a produção romanesca tende a aumentar, passando também a incluir autores cuja biografia não está marcada pela ditadura. A importância da maior valorização de romances está em que formas variadas de gêneros e narrativas tendem a contribuir a um alargamento das perspectivas narradas. Nas palavras de Renato Franco, a escrita ficcional ajuda a criar outro modo de percepção do momento histórico, e "sobretudo construir uma versão nova dos acontecimentos" (Franco, 2015, p. 218). O romance, assim, poderia favorecer a construção de uma memória coletiva mais heterogêna, uma vez que permitiria, potencialmente, a criação de novas versões sobre o passado.

\section{Referências}

AVELAR, Alexandre de Sá (2012). História, tempo presente e testemunho: ainda em torno dos limites da representação. Revista Marcanan, Rio de Janeiro, v. 8, n. 8, p. 29-58.

CARDOSO, Lucileide (2012). Criações da memória - Defensores e críticas da ditadura. Cruz das Almas: Editora da UFRB.

CATELA, Ludimila da Silva (2006). Presentación. In: POLLAK, Michael. Memória, olvido, silencio. La producción social de identidades frente a situaciones límite. La Plata: Al Margem. p. 9-15.

DALCASTAGNÈ, Regina (1996). O espaço da dor: o regime de 64 no romance brasileiro. Brasília: Editora da UnB.

FICO, Carlos (2004). Versões e controvérsias sobre 1964 e a ditadura militar. Revista Brasileira de História, São Paulo, v. 24, n. 47, p. 29-60.

\footnotetext{
${ }^{9}$ K. (2011), do jornalista Bernardo Kucinski, é um dos romances de maior projeção de público e crítica. O livro tem evidente teor autobiográfico, pois trata da história da irmã do autor, assassinada pelo regime. Entre os títulos de destaque recentemente publicados por editoras de médio e grande porte no Brasil estão: Não falei, de Beatriz Bracher (Editora34, 2004); Volto semana que vem, de Maria Pilla (CosacNaify, 2014) Outros cantos, de Maria Valéria Rezende, (Alfaguara, 2016), Amores exilados (Record, 2001 nova versão de obra publicada em 1997), de Godofredo de Oliveira Neto; Em nome do pai dos burros (Global, 2014), de Sílvio Lancellotti; Se eu olhar para trás, de Ademir Furtado (Dublinense, 2011), entre outros.

${ }^{10}$ Muitos livros são de edição do autor ou têm publicação independente; além disso, por si só, a referência no enredo não basta para catalogar o livro como sendo sobre a ditadura militar: é preciso que ela tenha importância estruturante na obra.
} 
FRANCO, Renato (1998a). Itinerário político do romance pós-64: A festa. São Paulo: Editora da Unesp.

FRANCO, Renato (1998b). O romance de resistência dos anos 70. In: INTERNATIONAL CONGRESS OF THE LATIN AMERICAN STUDIES ASSOCIATION (LASA), 21., 24 a 26 set. 1998, Chicago. Proceedings... Pittsburgh: LASA.

FRANCO, Renato (2015). Narrar o socialmente esquecido. Constelaciones: Revista de Teoría Crítica, n.7, dez., p. 202-221.

GABEIRA, Fernando (1979). O que é isso, companheiro? Rio de janeiro: Codecri.

GALVÃO, Walnice Nogueira (2014). Letras e artes: resistindo. Teoria e Debate, n. 122, 28 mar. On-line. Disponível em: https:/ / bit.ly/2zo33Kt. Acesso em: 20 fev. 2018.

GINZBURG, Jaime (2001). Escritas da tortura. Diálogos Latinoamericanos, Aarhus, n. 3, p. 131-146.

KOLLERITZ, Fernando (2004). Testemunho, juízo político e história. Revista Brasileira de História, São Paulo, v. 24, n. 48, p.73-100.

LAUB, Dori (1995). Truth and testimony: the process and the struggle. In: CARUTH, C. (Org). Trauma. Explorations in memory. Baltimore: Johns Hopkins University Press. p. 61-75.

LEGEUNE, Philippe (1989). The autobiographical pact. On autobiography. Tradução de Katherine Leary, Minneapolis: University of Minnesota Press. p. 3-30.

LUNGARETTI, Celso (2005). Náufrago da utopia. São Paulo: Geração.

MATHIAS, Marcello Duarte (2001). Autobiografias e diários: a memória dos outros. Lisboa: Gótica. p. 163-202.

MERTON, Robert (1972). Insiders and outsiders: a chapter in the sociology of knowledge. American Journal of Sociology, v. 78, n. 1, p. 9-47.

NETO, Godofredo de Oliveira (2011). Amores exilados. Rio de Janeiro: Record.

PAZ, Carlos Eugênio (1996/2009). Viagem à luta armada: memórias da guerrilha. Rio de Janeiro: BestBolso.

PELLEGRINI, Tânia (1987). Gavetas vazias? Uma abordagem da narrativa brasileira dos anos 1970. 252 f. Dissertação (Mestrado em Teoria Literária) - Universidade Estadual de Campinas, Campinas.

PHILLIPS, Mark Salber (2003). Relocating inwardness: historical distance and the transition from enlightenment to romantic historiography. PMLA, v. 118, n. 3, Special Issue: Imagining History, May, p. 436-449.

RIBEIRO, Maria Cláudia Badan (2005). Memória, história e sociedade: a contribuição da narrativa de Carlos Eugênio Paz. 283 f. Dissertação (Mestrado em Sociologia) - Universidade Estadual de Campinas, Campinas.

RODRIGUES, Maria Fernanda (2011). Páginas do país passado a limpo. O Estado de S. Paulo, 26 nov. Online. Disponível em: https:// bit.ly/2ku5Myd. Acesso em: 20 fev. 2018.

RUIVO, Marina Silva (2005). Literatura e resistência: estudo comparado de Viagem à luta armada, de Carlos Eugênio Paz, e A geração da utopia, de Pepetela. 285 f. Dissertação (Mestrado em Letras) - Universidade de São Paulo, São Paulo.

RUSSELL, Bertrand (1912/2001). Knowledge by acquaintence and knowledge by description. In: RUSSELL, Bertrand. The problems of philosophy. Oxford: Oxford University Press. p. 25-32.

RUSSELL, Bertrand (1918). Knowledge by acquaintance and knowledge by description. In: RUSSELL, Bertrand. Mysticism and logic and other essays. New York, London: Longmans, Green \& Co. p. 209-232.

SELIGMANN-SILVA, Márcio (2008). Narrar o trauma: a questão dos testemunhos de catástrofes históricas. Psicologia Clínica, Rio de Janeiro, v. 20, n. 1, p. 65-82.

TAPAJÓS, Renato (1977). Em câmara lenta. São Paulo: Alfa Omega.

TOZZI, Verónica (2012). The epistemic and moral role of testimony. History and Theory, v. 51, n. 1, p. 1-17. 